\title{
Aneuploidy mechanisms in human colorectal preneoplastic lesions and Barrett's esophagus. Is there a role for K-ras and p53 mutations?
}

\author{
Walter Giaretti \\ Laboratory of Biophysics and Cytometry, Istituto Nazionale per la Ricerca sul Cancro, \\ Largo Rosanna Benzi 10, 16132 Genova, Italy. Tel.: +39 10560 0969; Fax: +39 10560 0711; \\ Email: giaretti@hp380.ist.unige.it
}

Received 5 May 1997

Revised 1 June 1997

Accepted 10 June 1997

\begin{abstract}
The link of aneuploidy and heteroploidy in human solid tumours with early genetic events is poorly understood. The study of human preneoplastic precursor lesions, i.e., colorectal adenomas, chronic ulcerative colitis lesions, and Barrett's esophagus, as considered in this review, appears particularly useful to achieve this aim. Literature data examined here on aneuploidy were obtained by image and flow cytometry, classical cytogenetics, and in situ hybridization based cytogenetics. It appears that aneuploidy is linked with specific gene mutations, i.e., of the tumour suppressor gene p53 in chronic ulcerative colitis and in Barrett's esophagus, and of the protooncogene K-ras in colorectal adenomas. These data and data from experiments using in vitro and mouse models, suggest that chromosome instability, tetraploidization, and asymmetrical chromosome segregation during cell division are the result of deregulated cell cycle genes with multiple functions that normally exert active checks on the cell cycle processes including apoptosis and chromosome stability.
\end{abstract}

Keywords: Colorectal cancer, Barrett's esophagus, K-ras, p53, aneuploidy

\section{Introduction}

Aneuploidy, in the form of aberrant mitotic figures and abnormal morphology of interphase nuclei characterized by large size and hyperchromasia, has been an historic hallmark of cancer that goes back to the first two decades of this century $[22,23]$. However, it is still difficult to say what the significance of aneuploidy is. If aneuploidy is simply a side effect, then it should be seen as a reflection of an abnormal microenvironment and of a random series of epiphenomena. If, on the contrary, it is causally involved in tumourigenesis, it should be seen as a specific physiologic defect. Along with this last conceptual hypothesis it was proposed that ploidy and chromosome integrity are regulated by "active checks and balances" [142].

Tumorigenesis is a multistep process linked to hereditary and acquired genetic alterations. DNA alterations include activating mutations in oncogenes [24,209] and inactivating mutations in tumours 
suppressor [98,190], DNA repair [97,201], and in metastasis suppressor genes [15,18,191]. The hypothesis that a direct link exists between deregulation of some of these genes and generation of aneuploidy is not proven, although it was formulated long ago in the general form that a preneoplastic genetic event predisposes to more generalized chromosomal disruption [29,207]. On the other hand, a consistent involvement of only 71 of the 329 chromosomal bands of the human genome in primary neoplasia associated rearrengements [123] and fragility and instability of the chromosomes at specific sites [207], suggest general mechanisms of activation or inactivation of tumour associated genes by chromosomal changes. A model elaborated about 20 years ago on these concepts suggest that acquired genetic lability permits stepwise selection of variant sublines and underlies progression of tumours [134]. Although it was historically demonstrated that chromosomal translocations involving c-myc and c-abl were causative in Burkitt's lymphoma [98] and chronic myeloid leukaemia [38], it is hard to link chromosome changes and cancer genes in a cause-effect relationship. These concepts still are valid today but the exact mechanisms remain obscure.

Aneuploidy, detected by classical cytogenetics and, more recently, by image and flow cytometry, chromosome painting, and interphase cytogenetics, appears to be a characteristic of the vast majority of human tumours. Intratumour aneuploid cell subpopulations appear to be unstable, and to potentially regress or evolve and generate other subclones (heteroploidy). These subclones may have a different resistance to chemical and radiation therapies.

Development of aneuploidy and heteroploidy and their link with genetic events are better approached by investigating preneoplastic lesions. In the present review, human colorectal adenomas, chronic ulcerative colitis and Barrett's esophagus have been considered. These lesions may all progress to frank carcinomas, and, in particular, have been intensively investigated by molecular biology techniques that have provided partial knowledge about primary genetic events. This review suggests that specific genetic changes direct the process of aneuploidization. However, this is not yet proven and, in particular, it does not represent the commonly accepted view since many scientists believe that aneuploidy is an epiphenomenon of random origin.

\section{DNA instability}

DNA stability refers to multiple metabolic pathways that govern the maintenance of the primary DNA sequence, its correct duplication and postreplication proofreading as well as prevention and repair of DNA damage [32]. Mutational or exogenous interference with these multiple pathways determine DNA instability resulting in several effects such as new microsatellites alleles, gene amplification, single base substitutions, insertions, DNA deletions and recombinations. Mutations are also at the base of genetic evolution, and therefore, abnormal DNA instability must be considered to occur only above a normal threshold. For example, the $3 \times 10^{9}$ DNA bases of the human genome replicate with errors at a threshold frequency of about one in $10^{9}$ bases [32].

There is an important example of an inherited form of DNA instability in human hereditary nonpolyposis colorectal cancer, not found in the patient's normal cells. Ubiquitous new microsatellite alleles originate from simple DNA repeated sequences due to inherited defective mismatch repair genes (h MSH2, h MLH1 and h PMS2) whose normal functions are the control of DNA replication and repair, as recently reviewed [97]. Tumour cells with defective mismatch repair genes have been shown to have a mutation rate of two to three orders of magnitude higher than in normal cells $[16,45$, 186]. DNA microsatellite instability also occurs in the sporadic forms of colorectal tumours at about $10-15 \%$ level. Recently, APC mutations were studied in sporadic colorectal tumours with and without 
microsatellite instability. Surprisingly, a similar prevalence of the APC mutations was found [93], and equally unexpected was the finding that human colorectal tumours with microsatellite instability are also characterized by stable diploidy or only low incidence of near-diploid aneuploidy [101]. The vast majority of sporadic colorectal cancers, that have no apparent microsatellite instability (about $85 \%$ ) are, instead, characterized by gross DNA aneuploidy changes. These experimental data contrast with the hypothesis that aneuploidy is simply a random side effect reflecting an abnormal microenviroment or increased cell division. In fact, if this hypothesis is correct, we should expect that both hereditary and sporadic colorectal cancer (with and without DNA instability) have similar incidences of aneuploidy.

\section{Chromosome instability}

A common belief is that specific genetic mutations (of hypothetical "instability genes") induce DNA instability that then progresses into chromosome instability. Since these unproven hypotheses have generated some confusion, it may be better to define DNA instability and chromosome instability separately. They, in fact, seem to represent separate phenomena that may not be linked to the same genes. A further strong argument is that specific molecular mechanisms appear to control the maintenance of chromosome ploidy including chromosome packaging, correct interaction and movement on the mitotic spindle, centrosome duplication and movement, coordination with the cell cycle, interaction of DNA with topoisomerases, histone and nonhistone proteins, microtubules, centrioles, centromeres and telomeres $[32,78,128,142]$. In particular, chromosomes have been seen as active elements that play a role in their own movement during division [142] although this is not yet fully established [32,220].

Chromosome instability, in a large sense, could be defined to refer to all types of mechanisms leading to karyotipic alterations such as loss or gain of chromosomes as well as translocations, inversions, deletions, and include the mechanisms governing mitotic recombinations, chromosome replication and segregation during cell division $[9,32,76-78,90,99,117,142]$. The are essentially four examples of inherited chromosome instability in humans and are known as Bloom's syndrome, ataxia telangiectasia, Fanconi's anemia, and Werner syndrome $[31,33,173,174,178,195]$. These syndromes are characterized by a higher predisposition to cancer and, therefore, suggest an independent and causative role of aneuploidy in tumourigenesis.

\section{Detection of aneuploidy}

Aneuploidy has been classically approached by karyotyping that addresses both numerical and structural chromosome aberrations. However, the application of this methodology to human preneoplastic solid tumours showed that there were technicall difficulties in obtaining suitable cultures in vitro. In addition, this technique has the potential danger to introduce selection of fast growing subpopulations. Recently, fluorescence in situ hybridization (FISH) based cytogenetics in metaphase and in interphase nuclei has represented a clear advance for the detection of slight DNA ploidy differences including structural chromosome changes $[65,66,91,155,159]$. This type of approach, however, still requires tedious human visual analysis with use of fluorescence microscopy. Complementary methodologies are image and flow cytometry of cells or nuclei. While image analysis may preserve the tissue organization, flow cytometry requires the use of cell or nuclei suspensions. These techniques provide quantitative measurements of overall nuclear DNA content and, in particular, of the degree of DNA aneuploidy, relative to DNA diploid reference control cells (DNA Index, DI), but clearly not 
of specific numerical and structural chromosome aberrations [11]. Evaluation of the cell cycle phases and of the presence of multiple DNA abnormal cell heterogeneity is also feasible. In addition, flow cytometry offers the potential to sorting homogeneous cell subpopulations to submit to other analyses. Single parameter flow cytometry at high resolution of nuclei using fresh-frozen tissues with Dapi or Propidium Iodide staining provides, at best, detection of total DNA changes of about $\pm 2-4 \%[11,64$, $141,203,204]$. Multiparameter flow cytometry of nuclei suspensions may improve this resolution in some cases $[58,138,145,219]$.

\section{DNA tetraploidy}

"DNA tetraploidy" $(\mathrm{DI}=2)$ by DNA content flow cytometry is poorly defined since the measurements of the G2 and M phase cells are not separated and often doublets of G1 cells or nuclei are present. Flow cytometric "DNA tetraploid" cases may therefore indicate, in some cases, a simple increase of the number of mitotic abnormal cells and/or their increased residence time during M. Flow cytometric "DNA tetraploid" proliferating subclones, characterized by S-phase and G2+M fractions, are certainly rare in several tumour types especially, in early colorectal adenomas where they were detected at about the $2 \%$ level [56]. Cytogenetic evidence is clearly necessary for accurate definition of tetraploidy.

\section{Near-diploid aneuploidy}

Flow cytometric detection of DNA near-diploid aneuploidy with DNA content changes at the 3-4\% level is critical. In particular, some experimental conditions, like paraffin embedded material and large CVs, are not appropriate [3,154]. Near-diploid aneuploid artefacts due to different degrees of chromatin condensation and cell autolysis have been reported [219]. Chromatin conformation artefacts may occur for DNA intercalating stains [113]. Due to its non-intercalating mechanism of interaction with DNA and high quantum yield, DAPI staining appears to be a good choice $[64,141]$. Use of individual-specific and tissue-specific histologically proven normal mucosa is recommended. Multiparameter flow cytometry of nuclei suspensions using scattering signals permits the detection of cell autolysis and may help to select small DNA near-diploid aneuploid subclones [58,138,145,219]. DNA hypodiploidy may be particularly difficult to detect by flow cytometry due to the presence of background noise to the left of the DNA diploid peak [156]. Static computer-assisted cytometry on tumour cytological prints stained by the pararosaline Feulgen-Schiff technique may be suitable for detection of DNA hypodiploidy. In a recent study on lung cancer, DNA hypodiploidy incidence was detected at a $20 \%$ level among the aneuploid tumours and contributed significantly to survival in a Cox multivariate analysis [150].

DNA loss/gain changes lower than 3-4\% should be evaluated by techniques more sensitive than DNA flow and image cytometry. When classical cytogenetics and methaphase or interphase FISH cytogenetics were applied to cells from human colorectal adenomas, high incidences of near-diploid aneuploidy was shown $[7,20,68,83,84,111,162]$. The specific gain of chromosome 7 in human colorectal early adenomas, detected by classical and FISH cytogenetics, is an interesting example to consider $[83,84,111]$. Another example is the case of near-diploid lymphomas having retrovirally rearranged c-myc genes and duplicated the chromosome 15 carrying the rearranged c-myc [214]. Similarly, neardiploid aneuploidy was detected by classical and FISH cytogenetics of early bladder cancer showing 
that near-diploid aneuploidy was likely to be underestimated by flow cytometry performed under critical conditions $[143,175,183,184,189,211]$. Classical cytogenetics also showed frequent clonal numerical chromosomal changes into the near-diploid region with and without structural rearrangements for non-malignant human solid tumours of various histological types [196].

\section{Trisomies and DNA near-triploid aneuploidy}

Trisomies of the chromosomes $8,9,12$ and 21 by classical cytogenetics have been frequently reported $[81,82,123,124]$. In particular, trisomy of chromosome 7 represents an early event in colorectal carcinogenesis [83]. The biologic and pathogenic significance of such abnormalities still remains an enigma [69]. Current opinion is that these trisomies originate from a disease-related mitotic nondisjunction of chromosomes carrying normal or specific mutated genes [124]. This process is believed to invoke a gene dosage effect that initiates tumourogenesis. Trisomies of all 23 chromosomes have been observed as the sole karyotype abnormality both in hematologic malignancies and solid tumours [81, $82,124]$. When a similar situation occurs, it is expected that a flow cytometric measurement of DNA content would provide a DNA index in the near-triploid region (DI $=1.5 \pm 0.1)$. DNA near-triploidy evaluated by flow cytometry was observed at approximately $20 \%$ frequency among aneuploid colorectal adenocarcinomas [56,57]. The hypothesis that DNA near-triploid colorectal adenocarcinomas may reflect a different natural history is supported by recent data indicating that DNA near-triploid subclones are rarely K-ras mutated [57].

\section{Barrett's esophagus and aneuploidy}

Barrett's esophagus, characterized by squamous epithelial lining of the esophagus replaced by columnar epithelium, appears as a predisposing condition of most esophageal and gastroesophageal adenocarcinomas [188]. The risk of developing an adenocarcinoma in Barrett's esophagus was reported to be between 30-125 times that expected for a similar population without Barrett's esophagus [213]. Barrett's esophagus was suggested to be associated with the generation of multiple DNA aneuploid subpopulations, severe dysplastic changes in the abnormal mucosal lining of the esophagus and a series of genetic alterations $[158,163-165]$. The correlation between dysplastic changes and DNA aneuploidy has been demonstrated by flow cytometric techniques [85,158,163-165,181]. DNA aneuploidy was reported to be present in mucosa that is histologically negative for dysplasia as high as at $30 \%$ level and to represent a very early marker of tumourogenesis [85]. DNA aneuploidy incidence in Barrett's esophagus was reported with large variations in different studies. This is probably due to the critical sampling from the vast area of the lesion and to the different number of samples taken. The fraction of cells in the $\mathrm{G} 2+\mathrm{M}$ cell cycle phase was reported to be significantly higher than those of controls and near-diploid aneuploidy was also detected at high frequency $[116,181]$. The incidence of DNA aneuploidy in different studies may also depend on the critical definition of DNA tetraploidy and the difficulty in selecting near-diploid aneuploidy using flow cytometry (see above paragraphs). A few studies demonstrated clonal chromosome abnormalities in Barrett's epithelium and adenocarcinoma $[55,160,161,169]$. The karyotypes were often complex, but loss of the $\mathrm{Y}$ chromosome was a frequent finding [121]. 


\section{Aneuploidy in ulcerative colitis}

Chronic ulcerative colitis is a well established predisposing condition for the development of colorectal carcinomas $[69,94]$. The clinical development of carcinomas in ulcerative colitis and sporadic adenocarcinomas of the large bowel is quite different since in the latter case the precursor discrete sites of origin are adenomas without inflammation. Dysplasia in ulcerative colitis, instead, is preceded by a long history of chronic inflammation and often affects large regions of the colon. Histological progression in ulcerative colitis is characterized by a multistep process that includes aneuploidy and development of dysplasia $[3,26,74,107,109,110,120,157,206]$. Contrary to adenomas, where aneuploidy originates in dysplastic regions [157], DNA aneuploidy in precancerous chronic ulcerative colitis was also detected in regions of the mucosa that are indefinite for dysplasia [28].

\section{Aneuploidy in colorectal adenomas}

Dysplastic adenomas are seen as the focal precursors of most human adenocarcinomas of the large bowel [35,36,48,96,97,125,126,167]. Histologically, adenomas with mild, moderate and severe dysplasia are intermediate steps, and carcinomas infiltrating the intestinal wall through the muscularis mucosa are the endpoint of the sequence. Size increase in adenomas parallels grade of dysplasia [135], although small adenomas have been reported to regress completely [88]. The rate of malignant transformation of adenomas is about $0.25 \%$ per year [182] in association with number of polyps, histotype, size, grade of dysplasia and presence of atypical mitoses [125,126,129,171,182].

Kariotipic and flow cytometric DNA content aberrations in early preneoplastic colorectal adenomatous lesions are well documented [6,14,20,39,43,49,56,59,60,63,68,75,87,111,115,123,124,127,154, $162,166,168,180,192,202,210]$. Classical kariotype was not extensively investigated due to technical difficulties while FISH cytogenetics is becoming more frequent [91]. DNA flow cytometry on both fresh-frozen and paraffin embedded material was also performed on a large number of colorectal adenocarcinomas. For advanced tumours the reader is referred to a recent consensus review [11]. DNA aneuploidy incidences among colorectal adenomas (without and with early foci of cancer) range widely from approximately $10 \%$ to up to $70 \%[6,14,20,39,43,49,56,59,60,63,68,72,74,111,115,124$, $127,154,162,168,180,192,202,210]$. DNA near-diploid aneuploidy is a characteristic early event of the colorectal adenoma-carcinoma sequence $[56,58-60,202]$.

\section{1. p53 mutations and aneuploidy}

Mutations of the p53 tumour suppressor gene represent clues to human multistep carcinogenesis and cancer etiology [67]. Cultured fibroblasts from p53-deficient mouse embryos have shown the formation of tetraploid and octaploid cells, suggesting that murine p53 is a component of a spindle G2 checkpoint that ensures the maintenance of diploidy [37,52]. Similarly, in elastase-SV40 T antigen transgenic mice in which p53 is inactivated, tetraploid subclones seem to occurr followed by aneuploid subclones [139]. In this same model system, it was also shown that pancreatic cells were characterized by 4 and higher number of centrioles [106]. The role of p53 mutations in the induction of polyploidy and giant cells was also shown in p53 non-producer murine myelomonocytic leukemic cells reconstituted to express wild type or mutant p53 protein [144]. In particular, it was shown that nocodazol treated cells, fractionated by centrifugal elutriation for $>4 \mathrm{~N}$ DNA content, exibited an accellerated apoptosis as a 
result of wild type p53 expression while mutant p53 did not significantly alter the elimination of the giant cell population [144].

Mutations of the p53 tumour-suppressor gene have been established as an early event in the molecular mechanisms leading to esophageal squamous mucosa, known as Barrett's esophagus [13,19] and of colonic mucosa in patients with ulcerative colitis [217]. Allelic losses in 17p in diploid cells from the vast majority of patients with Barrett's esophagus who developped aneuploid cell populations were detected [19]. Surrounding Barrett's mucosa showed p53 mutations identical to that observed in the carcinomas [73]. The association of p53 inactivation and aneuploidy was reinforced by other studies $[54,105,152]$. Mutation of the p53 gene are, instead, infrequent in early colorectal adenomas and were shown to occur mainly during the conversion from adenoma to focal carcinoma $[4,5,137,205]$.

\section{K-ras mutations and aneuploidy}

The proteins encoded by the ras gene family bind guanine nucleotides, and act as signal transducers of diverse physiologycal signals. They posses an intrinsic GTPase activity and alternate between active and inactive forms (respectively, GTP-bound and GDP-bound). Ras oncogenes, activated by point mutations, are thought to contribute to many types of human cancer. Ras proteins may have additional functions as those toward cell growth or apoptosis determined by protein kinase $\mathrm{C}$ and Bcl-2 [216]. Other functions were also reported, for example those that regulate the formation of stress fibers, focal cell adhesion and cytokinesis, and should be further clarified [71,104,133]. Ras oncogenes were shown to be capable of transforming mouse and human cells in vitro and simultaneously to enhance chromosome instability $[119,151,187,208]$. Transfection of human mutated K-ras in mouse NIH-3T3 cells has been shown to induce destabilization of the chromosomes in mitosis $[70,132]$ and both DNA near-diploid and higher aneuploidy including tetraploidy [132]. Chromosome losses and chromatin textural changes using image cytometry [177] were shown to occur in H-ras transformed human breast epithelial cells $[10,119]$. Dependance of aneuploidy from H-ras mutations was shown in chemically induced mouse skin papillomas from very a early stage $[1,34,153]$. In particular, a non random duplication of the chromosome 7 bearing a mutated Ha-ras was demonstrated suggesting a mechanism of non-disjunction and further selection of near-diploid aneuploid cells with higher copy numbers of mutated Ha-ras genes [17].

The incidence of K-ras mutations in human colorectal adenomas, mainly in codons 12 and 13, is about $50 \%$ [21,48,80,205,206,212], similarly to the incidence of DNA aneuploidy [56,59,202]. K-ras mutations in colorectal adenomas were detected in both diploid and aneuploid cells and in some cases in regions of histologically normal mucosa suggesting that K-ras mutations occur before change in DNA ploidy [27]. Also colorectal aberrant crypt-foci, suggested to be early precursor lesions of adenomas, were found to be mutated in K-ras at about 50\% level [112,130,140,215].

K-ras2 transversions in human colorectal adenomas were associated with DNA near-diploid aneuploidy suggesting that K-ras2 transversions may be related to abnormal mitoses and near-diploid aneuploidy in a cause-effect relationship [58]. In ulcerative colitis and Barrett's esophagous K-ras mutations were only rarely detected in comparison to p53 mutations (see above).

\section{Other genes and aneuploidy}

Recent data obtained by classical cytogenetics [8] and interphase FISH [118] showed that 1p deletions are at a relatively high frequency (approximately 40\%) in colorectal adenomas. It has been 
suggested that genes located on the $1 \mathrm{p}$ chromosome arm (probably in the $1 \mathrm{p} 36$ region) play a role in the maintenance of chromosome stability [25,102]. These studies have indicated, in particular, that the deregulation of a human $58 \mathrm{kDA}$ protein kinase, encoded by a gene mapped on 1p36 region, increases the frequency of mitotic abnormalities and affects the rate of chromosomal numerical aberrations. Another possible interpretation is that mechanisms of aneusomy imply changes in methylation controlled by genes located in the human 1 p36 region. In fact, a "methylation modifier" gene was located in mouse chromosome 4 region synthenic to the human $1 \mathrm{p} 36$ band [44]. Defects of DNA methylation have been observed in colorectal tumours already prior to progression toward the malignant state [62] and appear to correlate with chromosomal instability [2,50] and with the induction of mitotic disturbances [194].

\section{The diploid-tetraploid transition model}

A Monte Carlo computer model was used to simulates the time dependent changes of the spontaneous mouse fibroblast transformation and progression in vitro [185]. This model suggests that aneuploidy in solid tumours is generated by the spontaneous tendency of diploid cancer cells to double their chromosome number and subsequently to loose chromosomes randomly. The condition for generating discrete aneuploid peaks would be the increased rate of structural abnormalities of the retained chromosomes in association with at least two independent growth-promoting gene activations that act in a dose-dependent way. Loss of tumour suppressor genes was not included in the model. The data so far obtained with the human preneoplastic Barrett's esophagous and colorectal ulcerative colitis have suggested that this model may apply as well to human systems in vivo where DNA tetraploidy and increased G2M cell cycle fractions have been experimentally observed. The frequency of DNA tetraploidy, mainly obtained by flow cytometry, was also expecially high, and was proposed as an early event, in germ cell tumour of the testis and in prostate cancer [46,146,197,200,221].

\section{The "loss of symmetry" model}

The model, mainly derived from the human colorectal adenoma-carcinoma sequence, postulates a mechanism of "loss of symmetry" in DNA repartition among sister chromatids and in chromosome segregation during cell division [56,58-60]. This model predicts that gene changes related to the cell cycle (in particular, to mitosis and apoptosis) may be responsible of abnormal mitoses ("delayed" in $\mathrm{M}$ due to chekpoints in G2M) and abnormal G1-postmitotic cells potentially able to generate neardiploid aneuploid cells/subclones in a non-random genetic driven process. The classical view of the stem cell theory, suggests that an abnormal mitosis would be "arrested" and would not generate abnormal G1-phase cells $[47,92,113,114,122,193]$. However, that abnormal mitoses may complete cell division, albeit during an increased time, and then begin another replication cycle was supported by different experiments $[40,41,132]$. Studies in vitro and in vivo, including in humans, showed a role of K-ras and H-ras activation in generating an abnormal mitotic process and aneuploidy (see above). In particular, human early colorectal adenomas show abnormal mitoses at high frequency [171], DNA aneuploid subclones (mostly near-diploid) at approximately 30-50\% level, and a strong association of DNA near-diploidy with K-ras mutations [56,58-60,202] (see also above). Experimental evidence, at least in colorectum data, suggest that near-diploid cells (in particular, hypodiploid cells) may undergo tetraploidization $[53,56,58-60,84,86]$. The concept of hypodiploidy as an early step of tumour aneuploidization evolution certainly fits with the increasingly recognized importance of chromosome loss (suppressor genes). 


\section{Discussion}

Aneuploidy is an historical hallmark of tumour cells [22,23,124,218]. However, it is still not clear whether aneuploidy should be regarded as an epiphenomenon of randoom origin or a specific physiologic defect that is causally involved in cancer. In the present review, the second hypothesis is preferred because of the non trivial consideration that it may be more fruitfull. The fact that the values of the degree of DNA aneuploidy as measured by flow cytometry (more correctly known as DNA Index values) do not show a flat distribution for most human tumours but characteristic peaks, such as for colorectal lesions, suggest that aneuploidy should not be an epiphenomenon of random origin.

Recently, literature reports have suggested that the wild type tumour suppressor gene p53 is implicated in a G1 checkpoint that directs the DNA damaged cells either to DNA repair or to apoptosis [67,103]. Moreover, inactivation of p53 was also associated with the origin of tetraploidy $[19,30,54$, $79,107,108,131,139$ ] suggesting, at least in mice, that p53 is a component of a spindle G2 checkpoint that ensures the maintenance of diploidy [37]. These and other basic investigations have suggested that wild type p53 functions as a guardian of the diploid set of the genome. Mutations of p53 occur frequently as an early event in diploid cells during the human neoplastic progression of Barrett's esophagus into adenocarcinomas $[13,54,131]$ and colorectal ulcerative colitis lesions predisposing to adenocarcinomas [217]. The inactivation of the p53 tumour suppressor gene in these human preneoplastic lesions was suggested to be in agreement with the diploid-tetraploid transition model (see above). Several reports, however, have shown that a certain number of DNA abnormal subclones were characterized by near-diploid aneuploidy (see above) and that advanced colorectal cancer showed that an increasing number of specific molecular lesions were associated with increased DNA Index values $[118,136]$. In particular, it is my opinion that the so called "DNA tetraploid" cases, so defined after measuring DNA content by flow cytometry, may well indicate a simple increase of the number of mitotic abnormal cells. Thus, it appears that alternative transitions to aneuploidy different from the diploid-tetraploid jump, may occur. It has been suggested that one mechanism (called "loss of symmetry") may lead to aneploidy from abnormal mitoses that segregate asymmetrically their chromosomes into unstable-intermediate near-diploid cells (in particular, hypodiploid cells) potentially able to endoduplicate into hypotetraploid and hypertetraploid cells (see above). Multiple centriole formation associated with p53 inactivation and consequent loss of control of G1 and G2 checkpoints can be associated to both models. In addition, the existence of cell cycle related "symmetry genes" that control equality of DNA in sister chromatids and symmetrical segregation of chromosome in mitosis may be postulated.

A third type of human preneoplastic lesion, colorectal adenomas, was considered in the present review. Contrary to Barrett's esophagous and colorectal ulcerative colitis, human colorectal adenomas are only rarely p53 mutated and show, instead, frequent K-ras oncogene activation and predominantely near-diploid aneuploidy (see above). That a cause-effect link exists between K-ras mutations and DNA aneuploidy in colorectal adenomas remains to be proven [58]. The observations, however, that a high expression of the mutated p21ras protein correlates with increased rates of abnormal mitosis in NIH3T3 cells [70,132] and the generation of a prevalence of near-diploid subclones [132], that abnormal mitoses in colorectal adenomas are massively present [171], that near-diploidy is strongly associated with K-ras mutations [58] seems to reinforce this hypothesis. Functions of the K-ras oncogene that are different from the classic signal transduction functions, i.e., those that regulate the formation of stress fibers, focal cell adhesion and cytokinesis, may play a role that should be further 
clarified [71,104,133]. The models of aneuploidization presented in this review based on a jump from diploidy to tetraploidy or on "loss of symmetry" in DNA cell division appear more frequently associated to p53 inactivation in ulcerative colitis and Barrett's esophagus, and to K-ras mutations in colorectal adenomas (see above). Therefore, it appears that aneuploidy may not be dismissed as a random epiphenomenon and that specific gene defects in cell cycle genes, like p53 and K-ras, may be responsible for the chromosome instability of cancer cells.

\section{Open questions and perspectives}

The processes generating DNA aneuploidy and heteroploidy, that characterize about $80 \%$ of the human epithelial tumours, are not yet entirely clarified. Few experimental studies have addressed the hypothesis that specific genetic changes may direct the process of aneuploidization in human solid tumours in vivo. Also the mechanisms that would increase the rate of gene mutations in tumours in processes mediated by increased structural abnormalities of the early aneuploid cells are not clear. Mitotic chromosome segregation occurs at high precision (errors are approximately $10^{-5}$ per generation) probably according to a redundant system optimazed for accuracy [9]. Much remains to be learned about the regulation of these activities that generate forces during cell division and the random or nonrandom processes of chromosome loss [117]. Sensing of the tension on the spindle is an important checkpoint as well as sensing the tension of certain kinetochore components. But more important, this concept appears to explain those regulatory events that integrate motor activity into the signal transduction cascades of the cell cycle [9].

Aneuploidy and heteroploidy appear to be generated as consequences of dynamic instability processes of DNA and chromosomes but still the genetic mechanisms that cause such instability are not clear $[32,76-78,89,90,117,142,170,172,176]$. Convergence and divergence scenarios $[51,81,100$, 123] as well as mechanisms of chaotic oscillation [61,147,179] were called into a more complex picture. A general concept is that one specific subclone overrides the other ones due to its gene activation/inactivations set that promotes increased proliferation and growth and reduced differentiation [134] and apoptosis [12]. Selection appears more important than increased mutation rate [93,97, 199]. Since cell division is instrumental to the fixation of genetic errors, an increased cell division should drive the accumulation and propagation of genetic errors. An increased proliferation due to endogenous and exogenous factors (hormones, drugs, infections, chemicals, physical or mechanical trauma, and other chronic irritation) may be seen as a decisive step of tumour progression [149]. For some cancer types (e.g., endometrium and ovary) this relationship is strong and well demonstrated, while for other cancers it is less clearly demonstrated but deserves full attention.

Mechanisms of aneuploidy selection and proliferation advantage of a given subline are likely to be of different types and to become sequentially operative at different times during the natural history of a neoplasm. Some of these mechanisms are likely to be of genetic origin [76,77] including the inheritance of epigenetic defects $[89,90]$ and cell-cell interactions between clonal subpopulations of tumour cells [148]. Recent data from the literature have shown that $1 \mathrm{p}$ deletions, as detected by FISH methodologies, represent an early event of the sporadic colorectal carcinogenesis [39] and that hypothetical specific genes deleted in this chromosome region might play a role in directing the process of methylation and aneuploidization [25,44,102]. The link of other early genetic events of the sporadic colorectal carcinogenesis with DNA aneuploidy-heterogeneity, like the APC gene and mismatch repair genes, has not been directly investigated and is also far from being understood. However, it is curious to observe that hereditary non-polyposis colorectal carcinomas, characterized by DNA repair gene 
mutations and microsatellites instability, have a clear DNA diploid predominance, suggesting that DNA and chromosome instabilities may be governed by independent mechanisms.

From the data presented in this review, it appears that inactivation of the p53 gene in colorecal ulcerative colitis and Barrett's esophagus and activation of K-ras oncogene in sporadic colorectal adenomas may predispose to aneuploidy. Among the multiple functions of p53 and K-ras, those related to apotosis and aneuploidy have not yet been fully understood. It is likely that the understanding of these mechanisms will improve rapidly and lead to a better understanding of the pathogenesis, regression, and progression of human solid tumour malignancies.

\section{Acknowledgements}

The author thanks the colleagues of his laboratory who have contributed to the research reviewed here including E. Geido and R. Orecchia for flow cytometry and sorting; A. Rapallo, S. Nigro, N. Pujic and A. Sciutto for molecular biology; A. di Vinci, E. Infusini and C. Peveri for FISH analysis. I also thank H. Aste (Gastroenterology, National Institute for Cancer Research, Genoa), F.P. Rossini (Gastroenterology, S. Giovanni Hospital, Turin), E. d'Amore (Pathology, University of Padova), M. Risio (Pathology, S. Giovanni Hospital, Turin) and R. Monaco (Pathology, Cardarelli Hospital, Naples) for providing tumour samples and for helpful collaboration and stimulating discussions.

This work was supported by the National Research Council (CNR) grant no. 96.00708.PF39 ACRO and by the Italian Association for Cancer Research "Tumori Colorettali Ereditari".

\section{References}

[1] C.M. Aldaz, C.J. Conti, A.J.P. Klein-Szanto and T.J. Slaga, Progressive dysplasia and aneuploidy are hallmarks of mouse skin papillomas: relevance to malignancy, Proc. Natl. Acad. Sci. USA 84 (1987), 2029-2032.

[2] A. Almeida, N. Kokalj-Vokac, D. Lefrancois, E. Viegas-Péquignot, M. Jeanpierre, B. Dutrillaux and B. Malfoy, Hypomethylation of classical satellite DNA and chromosome instability in lymphoblastoid cell lines, Hum. Genet. 91 (1993), 538-543

[3] N.C. Armitage, R.A. Robins, D.F. Evans, D.R. Turner, R.W. Baldwin and J.D. Hardcastle, The influence of tumour cell DNA abnormalities on survival in colorectal cancer, Br. J. Surg. 72 (1985), 828-830.

[4] S.J. Baker, E.R. Fearon, J.M. Nigro, S.R. Hamilton, A.C. Preisinger, J.M. Jessup, P. van Tuinen, D. Ledbetter, D.F. Barker, Y. Nakamura, R. White and B. Vogelstein, Chromosome 17 deletions and p53 mutations in colorectal carcinomas, Science 244 (1989), 217-221.

[5] S.J. Baker, A.C. Preisinger, J.M. Jessup, C. Paraskeva, S. Markowitz, J.K. Willson, S. Hamilton and B. Vogelstein, p53 gene mutations occur in combination with $17 \mathrm{p}$ allelic deletions as late events in colorectal tumourigenesis, Cancer Res. 50 (1990), 7717-7722.

[6] B.F. Banner, M.S. Chacho, D.L. Roseman and J.S. Coon, Multiparameter flow cytometric analysis of colon polips, Am. J. Pathol. 87 (1987), 313-318.

[7] G. Bardi et al., Cytogenetic analysis of 52 colorectal carcinomas: non-random aberration pattern and correlation with pathologic parameters, Int. J. Cancer 55 (1993), 422-428.

[8] G. Bardi, N. Pandis, C. Fenger, O. Kronborg, L. Bomme and S. Heim, Deletion of 1p36 as a primary chromosomal aberration in intestinal tumourigenesis, Cancer Res. 53 (1993), 1895-1898.

[9] N.R. Barton and L.S.B. Goldstein, Going mobile: microtubule motors and chromosome segregation, Proc. Natl. Acad. Sci. USA 93 (1996), 1735-1742.

[10] F. Basolo et al., Transformation of human breast epithelial cells by c-Ha-ras oncogene, Mol. Carcinogen 4 (1991), $25-35$.

[11] K.D. Bauer, C.B. Bagwell, W. Giaretti, M. Melamed, R.J. Zarbo, T.E. Witzig and P.S. Rabinovitch, Consensus review of the clinical utility of DNA flow cytometry in colorectal cancer, Cytometry 14 (1993), 486-491.

[12] A. Bedi, P.J. Pasricha, A.J. Akhtar, J.P. Barber, G.C. Bedi, F.M. Giardiello, B.A. Zehnbauer, S.R. Hamilton and R.J. Jones, Inhibition of apoptosis during development of colorectal cancer, Cancer Res. 55 (1995), 1811-1816. 
[13] W.P. Bennett, M.C. Hollstein, R.A. Metcalf, J.A. Welsh, A. He, S. Zhu, I. Kusters, J.H. Resau, B.F. Trump, D.P. Lane and C.C. Harris, p53 mutation and protein accumulation during multistage human esophageal carcinogenesis, Cancer Res. 52 (1992), 6092-6097.

[14] F. Beuvon, A. Laquerriere, B. Doublet and J. Hemet, Etude en cytométrie de flux des néoplasies polypoides du colon réséquées par endoscopie, Gastroenterol. Clin. Biol. 13 (1989), 671-675.

[15] G. Bevilacqua, M.E. Sobel, L.A. Liotta and P.S. Steeg, Association of low nm23 RNA levels in human primary infiltrating ductal breast carcinomas with lymph node involvement and other histopathological indicators of high metastatic potential, Cancer Res. (1989).

[16] N.P. Bhattacharya, A. Skandalis, A. Ganesh, J. Groden and M. Meuth, Mutator phenotypes in human colorectal adenocarcinoma cell lines, Proc. Natl. Acad. Sci. USA 91 (1994), 6319-6323.

[17] A.B. Bianchi, C.M. Aldaz and C.J. Conti, Non random duplication of the chromosome bearing a mutated Ha-ras-1 allele in mouse skin tumours, Proc. Natl. Acad. Sci. USA 87 (1990), 6902-6906.

[18] J.M. Bishop, The molecular genetics of cancer, Science 235 (1987), 305-311.

[19] P.L. Blount, P.C. Galipeau, C.A. Sanchez, K. Neshat, D.S. Levine, J. Yin, H. Suzuki, J.M. Abraham, S.J. Meltzer and B.J. Reid, 17p allelic losses in diploid cells of patients with Barrett's esophagus who develop aneuploidy, Cancer Res. 54 (1994), 2292-2295.

[20] L. Bomme, G. Bardi, N. Pandis, C. Fenger, O. Kronborg and S. Heim, Clonal karyotypic abnormalities in colorectal adenomas: clues to the early genetic events in the adenoma-carcinoma sequence, Genes Chromosome Cancer 10 (1994), 190-196.

[21] J.L. Bos, E.L. Fearon, S.R. Hamilton, M. Verlaan de Vries, J.H. van Boom, A.J. van der Eb and B. Vogelstein, Prevalence of ras gene mutations in human colorectal cancers, Nature 327 (1987), 293-296.

[22] T. Boveri, Zur Frage der Entstehung Maligner Tumoren, Gustav Fisher, Jena, 1914.

[23] A.C. Broders, Carcinoma grading and practical application, Arch. Path. 2 (1926), 376-385.

[24] I. Buckley, Oncogenes and the nature of malignancy, Adv. Cancer Res. 50 (1988), 71-94.

[25] B.A. Bunnell, L.S. Heath, D.E. Adams, J.M. Lahti and V.J. Kidd, Increased expression of a 58-kDa protein kinase leads to changes in the CHO cell cycle, Proc. Natl. Acad. Sci. USA 87 (1990), 7467-7471.

[26] G.C. Burmer, D.A. Crispin, V.R. Koli, R.C. Haggit, B.G. Kulander, C.E. Rubin and P.S. Rabinovitch, Frequent loss of a p53 allele in carcinomas and their precursor in ulcerative colitis, Cancer Communications 3 (1991), 167-172.

[27] G.C. Burmer and L.A. Loeb, Mutations in the K-ras2 oncogene during progressive stages of human colon carcinoma, Proc. Natl. Acad. Sci. USA 86 (1989), 2403-2407.

[28] G.C. Burmer, P.S. Rabinovitch, R.C. Haggitt, D.A. Crispin, T.A. Brentnall, V.R. Kolli, A.C. Stevens and C.E. Rubin, Neoplastic progression in ulcerative colitis: histology, DNA content, and loss of a p53 allele, Gastroenterology 103 (1992), 1602-1610.

[29] J. Cairns, The origin of human cancer, Nature 289 (1981), 353-357.

[30] P. Carder, A.H. Wyllie, C.A. Purdie, R.G. Morris, S. White, J. Piris and C.C. Bird, Stabilised p53 facilitates aneuploid clonal divergence in colorectal cancer, Oncogene 8 (1993), 1397-1401.

[31] R.S.K. Chaganti, S. Schonberg and J. German, A manyfold increase in sister chromatid exchange in Bloom's syndrome lymphocytes, Proc. Natl. Acad. Sci. USA (1974).

[32] K.C. Cheng and L.A. Loeb, Genomic instability and tumour progression: mechanistic considerations, Adv. Cancer Res. 60 (1993), 121-156.

[33] M.M. Coehn, M. Shaham, J. Dagan, E. Shmueli and G. Khon, Cytogenetic investigation in families with ataxia telangiectasia, Cytogenet. Cell Genet. 15 (1975), 338-356.

[34] C.J. Conti, C.M. Aldaz, J. O'Connell, A.J.P. Klein-Szanto and T.J. Slaga, Aneuploidy, an early event in mouse skin tumour development, Carcinogenesis 7 (1986), 1845-1848.

[35] P. Correa, J.P. Strong, A. Reif and W.D. Johnson, The epidemiology of colorectal polyps. Prevalence in New Orleans and international comparison, Cancer 39 (1977), 2258-2264.

[36] B.E. Crawford and F.W. Stromeyer, Small nonpolypoid carcinoma of the large intestine, Cancer 51 (1983), 17601763.

[37] S.M. Cross, C.A. Sanchez, C.A. Morgan, M.K. Schimke, S. Ramel, R.L. Idzerda, W.H. Raskind and B.J. Reid, A p53-dependent mouse spindle checkpoint, Science 267 (1995), 1353-1356.

[38] A. de Klein, A.G. van Kessel, G. Grosveld, C.R. Bartram, A. Hagemeyer, D. Bootsma, N.K. Spurr, N. Heisterkamp, J. Groffen and G.R. Stephenson, A cellular oncogene is translocated to the Philadelphia chromosome in chronic myelocitic leukaemia, Nature 300 (1982), 765-767.

[39] A. Di Vinci, E. Infusini, C. Peveri, M. Risio, F.P. Rossini and W. Giaretti, Deletions at chromosome 1p by fluorescence in situ hybridization are an early event in human colorectal tumourigenesis, Gastroenterology 111 (1996), 102-107.

[40] W.C. Dooley and D.C. Allison, Non-random distribution of abnormal mitoses in heteroploid cell lines, Cytometry 13 (1992), 462-468. 
[41] W.C. Dooley, D.C. Allison and J. Robertson, Discrepancies among the meaphase, telophase, and the G0/G1 and G2 DNA peaks of heteroploid cell lines, Cytometry 12 (1991), 99-106.

[42] T.J. Eide, Risk of colorectal cancer in adenoma bearing individuals within a defined population, Int. J. Cancer 38 (1986), 173-176.

[43] P. Enblad and B. Glimelius, The DNA content in rectal adenomas, Anticancer Research 9 (1989), 749-752.

[44] P. Engler et al., A strain-specific modifier on mouse chromosome 4 controls the methylation of independent transgene loci, Cell 65 (1991), 939-945.

[45] J.R. Eshelman, E.Z. Lang, G.K. Bowerfind, R. Parsons, B. Vogelstein, J.K. Wilson, M.L. Veigl, W.D. Sedwick and S.D. Markowitz, Increased mutation rate at the hprt locus accompanies microsatellites instability in colon cancer, Oncogene 10 (1995), 33-37.

[46] D.P. Evenson and M.R. Melamed, Rapid analysis of normal and abnormal cell types in human semen and testis biopsies by flow cytometry, J. Histochem. Cytochem. 31 (1983), 248-253.

[47] J.C. Fardon and J.E. Prince, A comparison of the ratios of metaphase to prophase in normal and neoplastic tissues, Cancer Res. 12 (1952), 793-797.

[48] E.R. Fearon and B. Vogelstein, A genetic model for colorectal tumourigenesis, Cell 61 (1990), 759-767.

[49] W. Fischbach, J. Mossner, H. Seyschab and H. Hohn, Tissue carcinoembryonic antigen and DNA aneuploidy in precancerous and cancerous colorectal lesions, Cancer 65 (1990), 1820-1824.

[50] H.M. Foss, C.J. Roberts, K.M. Claeys and E.U. Selker, Abnormal chromosome behavior in neurospora mutants defective in DNA methylation, Science 262 (1993), 1737-1739.

[51] H. Fujii, C. Marsh, P. Cairns, D. Sidransky and E. Gabrielson, Genetic divergence in the clonal evolution of breast cancer, Cancer Res. 56 (1996), 1493-1497.

[52] K. Fukasawa, C. Taesaeng, R. Kuriyama, S. Rulong and G.F. van de Woude, Abnormal centrosome amplification in the absence of p53, Science 271 (1996), 1744-1747.

[53] S. Gagos, D. Iliopoulos, S. Tseleni-Balafouta, M. Agapitos, C. Antachopoulos, A. Kostakis, P. Karayannakos and G. Skalkeas, Cell senescence as a mechanism of clonal evolution leading to continuous cell proliferation, loss of heterozygosity, and tumour heterogeneity: studies on two immortal colon cancer cell lines, Cancer Genet. Cytogenet. 90 (1996), 157-165.

[54] P.C. Galipeau, D.S. Cowan, C.A. Sanchez, M.T. Barrett, M.J. Emond, D.S. Levine, P.S. Rabinovitch and B.J. Reid, 17p (p53) allelic losses, 4N (G2/tetraploid) populations, and progression to aneuploidy in Barrett's esophagus, Proc. Natl. Acad. Sci. USA 93 (1996), 7081-7084.

[55] H.S. Garewal, R. Sampliner, Y. Liu and J.M. Trent, Chromosomal rearrangements in Barrett's esophagus. A premalignant lesion of esophageal adenocarcinoma, Cancer Genet. Cytogenet. 42 (1989), 281-296.

[56] W. Giaretti, A model of DNA aneuploidization and evolution in colorectal cancer, Lab. Invest. 71 (1994), 904-910.

[57] W. Giaretti, R. Monaco, N. Pujic, A. Rapallo, S. Nigro and E. Geido, Intratumour heterogeneity of K-ras2 mutations in colorectal adenocarcinomas. Association with degree of DNA aneuploidy, Am. J. Pathology 149 (1996), 237-245.

[58] W. Giaretti, N. Pujic, A. Rapallo, S. Nigro, A. Di Vinci, E. Geido and M. Risio, K-ras2 G-C and G-T transversions correlate with DNA aneuploidy in colorectal adenomas, Gastroenterology 108 (1995), 1040-1047.

[59] W. Giaretti and L. Santi, Tumour progression by DNA flow cytometry in human colorectal cancer, Int. J. Cancer 45 (1990), 597-603.

[60] W. Giaretti, S. Sciallero, S. Bruno, E. Geido, H. Aste and A. Di Vinci, DNA flow cytometry of endoscopically examined colorectal adenomas and adenocarcinomas, Cytometry 9 (1988), 238-244.

[61] R.W. Glenny and H.T. Robertson, Fractal modeling of pulmonary blood flow heterogeneity, J. Appl. Physiol. 70 (1991), 1024-1030.

[62] S.E. Goelz, B. Vogelstein, S.R. Hamilton and A.P. Feinberg, Hypomethylation of DNA from benign and malignant human colon neoplams, Science 228 (1985), 187-190.

[63] H.S. Goh and J.R. Jass, DNA content and the adenoma-carcinoma sequence in the colorectum, J. Clin. Pathol. 39 (1986), 387-392.

[64] W. Göhde, J. Schuman and J. Zante, The use of DAPI in pulse cytophotometry, in: Pulse Cytophotometry, D. Lutz, ed., Ghent, 1978 pp. 229-232.

[65] J.W. Gray and D. Pinkel, Molecular cytogenetics in human cancer diagnosis, Cancer 69 (1992), 1536-1542.

[66] J.W. Gray, D. Pinkel and J.M. Brown, Fluorescence in situ hybridization in cancer and radiation biology, Radiation Research 137 (1994), 275-289.

[67] M.S. Greenblatt, W.P. Bennet, M. Hollstein and C.C. Harris, Mutations in the p53 suppressor gene: clues to cancer etiology and molecular pathogenesis, Cancer Res. 54 (1994), 4855-4878.

[68] C.A. Griffin, S. Lazer, S.R. Hamilton, F.M. Giardiello, P. Long, A.J. Krush and S.V. Booker, Cytogenetic analysis of intestinal polyps in polyposis syndromes: Comparison with sporadic colorectal adenomas, Cancer Genet. Cytogenet. 67 (1993), 14-20.

[69] O.A. Haas and M. Seyger, Meiotic origin of trisomic neoplasm, Cancer Genet. Cytogenet. 70 (1993), 112-116. 
[70] N. Hagag, L. Diamond, R. Palermo and S. Lyubsky, High expression of ras p21 correlates with increased rate of abnormal mitosis in NIH3T3 cells, Oncogene 5 (1990), 1481-1489.

[71] A. Hall, Small GTP-binding proteins and the regulation of the actin cytoskeleton, Ann. Rev. Cell Biol. 10 (1994), 31-54.

[72] S. Hamada, K. Namura, R. Itoh and S. Fujita, Characteristics of colorectal epithelia and adenomas as revealed by DNA cytofluorimetry, Jpn. J. Cancer Res. 78 (1987), 826-832.

[73] R. Hamelin, J.F. Fléjou, F. Muzeau, F. Potet, P. Laurent-Puig, F. Fékété and G. Thomas, TP53 gene mutations and p53 protein immunoreactivity in malignant and premalignant Barett's esophagus, Gastroenterology 107 (1994), 1012-1018.

[74] C. Hammarberg, P. Slezak and B. Tribukait, Early detection of malignancy in ulcerative colitis, Cancer 53 (1984), 291-295.

[75] C. Hammarberg, B. Tribukait, C. Rubio and P. Slezak, Application clinique de la citométrie de flux de l'ADN à la caractérisation des polypes colorectaux, Acta Endoscopica 15 (1985), 265-274.

[76] L. Hartwell, Defects in a cell cycle checkpoint may be responsible for the genomic instability of cancer cells, Cell 71 (1992), 543-546.

[77] L. Hartwell and M.B. Kastan, Cell cycle control and cancer, Science 266 (1994), 1821-1828.

[78] L.H. Hartwell and T.A. Weinert, Checkpoints: Controls that ensure the order of cell cycle events, Science 246 (1989), 629-634.

[79] M. Harvey, A.T. Sands, R.S. Weiss, M.E. Hegi, R.W. Wiseman, P. Pantazis, B.C. Giovanella, M.A. Tainsky, A. Bradley and L.A. Donehower, In vitro characteristics of embryo fibroblast isolated from p53-deficient mice, Oncogene 8 (1993), 2457-2467.

[80] H. Hasegawa, M. Ueda, M. Watanabe, T. Teramoto, M. Mukai and M. Kitajima, K-ras gene mutations in early colorectal cancer ... flat elevated vs. polyp-forming cancer. .., Oncogene 10 (1995), 1413-1416.

[81] S. Heim and F. Mitelman, Chromosomal abnormalities in specific disorders: solid tumours, in: Cancer Cytogenetics, S. Heim and F. Mitelman, eds, Alan R. Liss, New York, 1987, p. 227.

[82] S. Heim and F. Mitelman, Numerical chromosome aberration in human neoplasia, Cytogenet. Cell Genet. 22 (1986), 99-108.

[83] J. Herbergs, A.P. de Bruine, P.T.J. Marx, M.I.J. Vallinga, R.W. Stockbrügger, F.C.S. Ramaekers, J.W. Arends and A.H.N. Hopman, Chromosome aberrations in adenomas of the colon. Proof of trisomy 7 in tumour cells by combined interphase cytogenetics and immunohistochemistry, Int. J. Cancer 57 (1994), 781-785.

[84] J. Herbergs, A.H.N. Hopman, A.P. de Bruine, F.C.S. Ramaekers and J.W. Arends, In situ hybridization and flow cytometric analysis of colorectal tumours suggests two routes of tumourigenesis characterized by gain of chromosome 7 or loss of chromosome 17 and 18, J. Pathol. 179 (1996), 243-247.

[85] R.D. Herman, M.J. McKinley, R.L. Bronzo, G.S. Weissman, I.S. Goldman, E. Khan and L. Stiel, Flow cytometry and Barrett's esophagus, Digestive Disease and Science 37 (1992), 635-637.

[86] W. Hiddeman, von Bassewitz, H.J. Kleinemeier, E. Schulte-Brochterbeck, J. Hauss, B. Lingemann, T. Büchner and E. Grundmann, DNA stemline heterogeneity in colorectal cancer, Cancer 58 (1986), 258-263.

[87] G. Hoff, O.P.F. Clausen, Fjordvang, A. Norheim, A. Foerster and M.H. Vatn, Epidemiology of polyps in the rectum and sigmoid colon, Scand. J. Gastroenterol. 20 (1985), 983-989.

[88] G. Hoff, A. Foerster, M.J. Vatn, J. Savar and S. Larsen, Epidemiology of polyps in the rectum and colon. Recovery and evolution of unresected polyps 2 years after detection, Scand. J. Gastroenterol. 21 (1986), 853-862.

[89] R. Holliday, The inheritance of epigenetic defects, Science 238 (1987), 163-170.

[90] R. Holliday and P.A. Jeggo, Mechanisms for changing gene expression and their possible relationship to carcinogenesis, Cancer Surveys 4 (1985), 558-581.

[91] A.H.N. Hopman, F.C.S. Ramaekers, A.K. Raap, J.L.M. Beck, P. Devilee, M. van der Ploeg and G.P. Voijs, In situ hybridization as a tool to study numerical chromosome aberrations in solid bladder tumours, Histochemistry 89 (1988), 307-316.

[92] T.C. Hsu and P.S. Moorhead, Chromosome anomalies in human neoplams with special reference to the mechanisms of polyploidization and aneuploidization in HeLa strain, Ann. NY Acad. Sci. 63 (1956), 1083-1088.

[93] J. Huang, Papadopoulos, A.J. McKinley, S.M. Farringtom, L.J. Curtis, A.H. Wyllie, S. Zheng, J.K.V. Willson, S.D. Markovitz, P. Morin, K.W. Kinzler, B. Vogelstein and M.G. Dunlop, APC mutations in colorectal tumours with mismatch repair deficiency, Proc. Natl. Acad. Sci. USA 93 (1996), 9049-9054.

[94] G. Isbell and B. Levin, Ulcerative colitis and colon cancer, Clin. Gastroenterol. 17 (1988), 773-791.

[95] W.K. Kaufmann, Cell cycle checkpoints and DNA repair preserve the stability of the human genome, Cancer Met. Rev. 14 (1995), 31-41.

[96] Y.S. Kim and S.H. Itskowitz, Carbohydrate antigen expression in the adenoma-carcinoma sequence, in: Basic and Clinic Perspectives of Colorectal Polyps and Cancer, J. Steele, R. Burt, S.J. Winawer and J.P. Karr, eds, Alan R. Liss, New York, 1988. 
[97] K.W. Kinzler and B. Vogelstein, Lesson from hereditary colorectal cancer, Cell 87 (1996), 159-170.

[98] G. Klein, The role of gene dosage and genetic transpositions in carcinogenesis, Nature 294 (1981), 313-318.

[99] H.L. Klein, Recombination of Genetic Material, K.B. Low, ed., Academic Press, San Diego, 1988, pp. 385-421.

[100] W.T. Knöfel, U. Otto, H. Baisch and G. Klöppel, Stability of human renal cell carcinoma during long term serial transplantation into nude mice: histopathology, nuclear grade, mitotic rate, and DNA content in thirty tumours, Cancer Res. 47 (1987), 221-224.

[101] M. Kouri, A. Laasonen, J.P. Mecklin, H. Järvinen, K. Franssila and S. Pyrhönen, Diploid predominance in hereditary nonpolyposis colorectal carcinoma evaluated by flow cytometry, Cancer 65 (1990), 1825-1829.

[102] J.M. Lahti, J. Xiang, L.S. Heath, D. Campana and V.J. Kidd, PITSLRE protein kinase activity is associated with apoptosis, Mol. Cell Biol. 15 (1995), 1-7.

[103] D.P. Lane, p53, guardian of the genome, Nature 358 (1992), 15-16.

[104] D.A. Larochelle, K.K. Vithalani and A. de Lozanne, A novel member of the rho family of small GTP-binding proteins is specifically required for cytokinesis, J. Cell Biol. 133 (1996), 1321-1329.

[105] D.S. Levine, Barrett's esophagus and p53, The Lancet 344 (1994), 212-213.

[106] D.S. Levine, Formation of the tetraploid intermediate is associated with the development of cell with more than four centrioles in the elastase-simian virus 40 tumour antigen transgenic mouse model of pancreatic cancer, Proc. Natl. Acad. Sci. USA 88 (1991), 6427-6431.

[107] D.S. Levine, P.S. Rabinovitch, R.C. Haggit, P.L. Blount, P.J. Dean, C.E. Rubin and B.J. Reid, Distribution of aneuploid cell populations in ulcerative colitis with dysplasia or cancer, Gastroenterology 101 (1991), 1198-1210.

[108] L.R. Livingstone, A. White, J. Sprouse, E. Livanos, T. Jacks and T.D. Tlsty, Altered cell cycle arrest and gene amplification potential accompany loss of wild-type p53, Cell 70 (1992), 923-935.

[109] R. Löfberg, T. Caspersson, B. Tribukait and Å. Öst, Comparative DNA analyses in longstanding ulcerative colitis with aneuploidy, Gut 30 (1989), 1731-1736.

[110] R. Löfberg, B. Tribukait, Å. Öst, O. Broström and H. Reichard, Flow cytometric DNA analysis in longstanding ulcerative colitis: a method of predicion of dysplasia and carcinoma development, Gut 28 (1987), 1100-1106.

[111] M. Longy, R. Saura, F. Dumas, J.F. Leseve, L. Taine, J.F. Goussot and P. Couzigou, Chromosome analysis of adenomatous polyps of the colon, Cancer Genet. Cytogenet. 67 (1993), 7-13.

[112] L. Losi, L. Roncucci, C. di Gregorio, M. Ponz de Leon and J. Benhattar, K-ras and p53 mutations in human colorectal aberrant crypt foci, J. Pathol. 178 (1996), 259-263.

[113] S. Makino, Further evidence favoring the concept of the stem cell in ascites tumours of rats, Ann. NY Acad. Sci. 63 (1956), 818-822.

[114] S. Makino, Neoplasia, in: Human Chromosomes, Igaku Shoin, Tokio, 1987, pp. 429-462.

[115] J. Matthews, S. Sousha, R.A. Parkins, M. Glynn and T. Cooke, Proliferation patterns and aneuploidy in adenomatous polyps of the colon, Br. J. Surg. 75 (1988), 906-909.

[116] M.J. Mckinley, D.R. Budman, D. Grueneberg, R.L. Bronzo, G.S. Weissman and E. Kahn, DNA content in Barrett's esophagus and esophageal malignancy, Am. J. Gastroenterol. 82 (1987), 1012-1015.

[117] D. Meeks-Wagner and L.H. Hartwell, Normal stoichiometry of histone dimer sets is necessary for high fidelity of mitotic chromosome transmission, Cell 44 (1986), 43-52.

[118] G.I. Meling et al., The TP53 tumour suppressor gene in colorectal carcinomas. II. Relation to DNA ploidy pattern and clinicopathological variables, Br. J. Cancer 67 (1993), 93-98.

[119] M.L.S. Mello, T.Y. Lin and J. Russo, Scanning microphotometry image analysis of Ha-ras-transformed human breast epithelial cells, Anal. Cell. Pathol. 7 (1994), 301-319.

[120] D.M. Melville, J.R. Jass, N.A. Sheperd, J.M.A. Northover, D. Capellaro, P.I. Richman, J.E. Lennard-Jones, J.K. Ritchie and S.N. Anderson, Dysplasia and deoxyribonucleic acid aneuploidy in the assesment of precancerous changes in chronic ulcerative colitis, Gastroenterology 95 (1988), 668-675.

[121] M.B.E. Menke-Pluymers, E. van Drunen, K.J. Vissers, A.H. Mulder, H.W. Tilanus and A. Hagemeijer, Cytogenetic analysis of Barrett's mucosa and adenocarcinoma of the distal esophagus and cardia, Cancer Genet. Cytogenet. 90 (1996), 109-117.

[122] T.J. Mitchison, Mitosis: basic concepts, Curr. Op. Cell Biol. 1 (1989), 67-74.

[123] F. Mitelman and S. Heim, Consistent involvment of only 71 of the 329 chromosomal bands of the human genome in primary neoplasia-associated rearrangements, Cancer Res. 48 (1988), 7115-7119.

[124] F. Mitelman, Y. Kanako and J. Trent, Report of the committee on chromosome changes in neoplasia, Cytogenet. Cell Genet. 58 (1991), 1053-1079.

[125] B.C. Morson, The polyp-cancer sequence in the large bowel, Proc. Roy. Soc. Med. 67 (1974), 451-454.

[126] B.C. Morson, I.M.P. Dawson, J.R. Jass, A.B. Price and G.T. Williams, Morson and Dawson's Gastrointestinal Pathology, 3rd edn, Blackwell Scientific Publications, Oxford, 1990.

[127] T. Murad, K. Bauer and D.G. Scarpelli, Histopathologic and flow cytometric analysis of adenomatous colonic polyps, Arch. Pathol. Lab. Med. 113 (1989), 1003-1008. 
[128] A.W. Murray and M.W. Kirschner, Dominoes and clocks: the union of two views of the cell cycle, Science 246 (1989), 614-621.

[129] T. Muto, H.J.R. Bussey and B.C. Morson, The evolution of cancer of the colon and rectum, Cancer 36 (1975), 2251.

[130] S. Nakamura, J. Goto, M. Kitayama and I. Kino, Application of the crypt-isolation technique to flow-cytometric analysis of DNA content in colorectal neoplasms, Gastroenterology 106 (1994), 100-107.

[131] K. Neshat, C.A. Sanchez, P.C. Galipeau, P.L. Blount, D.S. Levine, G. Joslyn and B.J. Reid, p53 mutations in Barrett's adenocarcinoma and high-grade dysplasia, Gastroenterology 106 (1994), 1589-1595.

[132] S. Nigro, E. Geido, E. Infusini, R. Orecchia and W. Giaretti, Transfection of human mutated K-ras in mouse NIH-3T3 cells is associated with increased cloning efficiency and DNA aneuploidization, Int. J. Cancer 67 (1996), 871-875.

[133] C.D. Nobes and A. Hall, Rho, rac, and cdc42 GTPases regulate the assembly of multimolecular focal complexes associated with actin stress fibers, lamellipodia, and filopodia, Cell 81 (1995), 53-62.

[134] P.C. Nowell, The clonal evolution of tumour cell populations. Acquired genetic lability permits stepwise selection of variant sublines and underlies tumour progression, Science 194 (1976), 23-28.

[135] M.J. O’Brien et al., The national polyp study: determinants of high grade dysplasia in colorectal adenomas, Gastroenterology 98 (1990), 371-379.

[136] G.J.A. Offerhaus et al., The relationship of DNA aneuploidy to molecular genetic alterations in colorectal carcinoma, Gastroenterology 102 (1992), 1612-1619.

[137] M. Ohue, N. Tomita, T. Monden, M. Fujita, M. Fukunaga, K. Tkami, I. Yana, T. Ohnishi, T. Enomoto, M. Inoue, T. Shimano and T. Mori, A frequent alteration of p53 gene in carcinoma in adenoma of colon, Cancer Res. 54 (1994), 4798-4804.

[138] M.G. Ormerod, J.C. Titley and P.R. Imrie, Use of light scatter when recording a DNA histogram from paraffinembedded tissue, Cytometry 21 (1995), 294-299.

[139] D.M. Ornitz, R.E. Hammer, A. Messing, R.D. Palmiter and R.L. Brinster, Pancreatic neoplasia induced by SV-40 T-antigen expression in acinar cells of transgenic mice, Science 238 (1987), 188-193.

[140] K. Otori, K. Sugijama, T. Hasebe, S. Fukushima and H. Esumi, Emergence of adenomatous aberrant crypt foci (ACF) from hyperplastic ACF with concomitant increase in cell proliferation, Cancer Res. 55 (1995), 4743-4746.

[141] F. Otto, Dapi staining of fixed cells for high-resolution flow cytometry of nuclear DNA, Meth. Cell Biol. 33 (1990), 105-119.

[142] M.L. Pardue, Dynamic instability of chromosome and genomes, Cell 66 (1991), 427-431.

[143] R. Pauwels and W. Smeets, Cytogenetics studies in bladder cancer, Probl. Urol. 2 (1992), 297-319.

[144] A. Peled, D. Schwartz, N. Barry Elkind, R. Wolkowicz, R. Li and V. Rotter, The role of p53 in the induction of poliploidity of myelomonocytic leukemic M1/2 cells, Oncogene 13 (1996), 1677-1685.

[145] J. Pétriz, D. Tugues and J. García-Lòpez, Relevance of forward scatter and side scatter in aneuploidy detection by flow cytometry, Anal. Cell. Pathol. 10 (1996), 243-252.

[146] P. Pfitzer, P. Gilbert, G. Roly and K. Vyska, Flow cytometry of human testicular tissue, Cytometry 3 (1982), 116-122.

[147] E.M. Posadas, S.R. Criley and D.S. Coffey, Chaotic oscillations in cultured cells: rat prostate cancer, Cancer Res. 56 (1996), 3682-3688.

[148] G. Poste, J. Doll and I.J. Fidler, Interactions between clonal subpopulations affect the stability of the metastatic phenotype in polyclonal populations of B16 melanoma cells, Proc. Natl. Acad. Sci. USA 78 (1981), 6226-6230.

[149] S. Preston-Martin, M.C. Pike, R.K. Ross, P.A. Jones and B.E. Henderson, Increased cell division as a cause of human cancer, Cancer Res. 50 (1990), 7415-7421.

[150] J.I. Pujol, J. Simony, J. Jolimoy, D. Jaffuel, P. Demoly, X. Quantin, C. Marty-Ané, J.E. Boher, R. Charpentier and F.B. Michel, Hypodiploidy, Ki-67 growth fraction and prognosis of surgically resected lung cancers, Br. J. Cancer 74 (1996), 964-970.

[151] S. Pulciani, E. Santos, A.V. Lauver, L.K. Long, S.A. Aaronson and D. Barbacid, Oncogenes in solid human tumours, Nature 300 (1982), 539-542.

[152] C.A. Purdie, D.J. Harrison, A. Peter, L. Dobbie, S. White, S.E.M. Howie, D.M. Salter, C.C. Bird, A.H. Wyllie, M.L. Hooper and A.R. Clarke, Tumour incidence, spectrum and ploidy in mice with a large deletion in the p53 gene, Oncogene 9 (1994), 603-609.

[153] M. Quintanilla, K. Brown, M. Ramsden and A. Balmain, Carcinogen specific mutation and amplification of Ha-ras during mouse skin carcinogenesis, Nature 322 (1986), 78-80.

[154] P. Quirke, J.B.J. Fozard, M.F. Dixon, J.E.D. Dyson, G.R. Giles and C.C. Bird, DNA aneuploidy in colorectal adenomas, Br. J. Cancer 53 (1986), 477-481.

[155] A.K. Raap, P.M. Nederlof, R.W. Dirks, J.C.A.G. Wiegant and M. van der Ploeg, Use of haptenized nucleic acid probes in fluorescent in situ hybridization, in: In Situ Hybridization: Application to Developmental Biology and Medicine, N. Harris and D.G. Williams, eds, Cambridge University Press, Cambridge, 1990.

[156] P.S. Rabinovitch, DNA content histogram and cell-cycle analysis, in: Methods in Cell Biology, Z. Darzynkiewicz, J.P. Robinson and H.A. Crissman, eds, Vol. 41, Academic Press, 1994, pp. 263-296. 
[157] P.S. Rabinovitch, G.C. Burmer, R.C. Haggit, D.S. Levine, C.E. Rubin and B.J. Reid, Flow cytometric changes that precede cancer: premalignant gastrointestinal disease, in: New Technologies in Cytometry, G.C. Salzman, ed., Proc. Int. Soc. Optical Engineering, Vol. 1063, Bellingham, WA, 1989, pp. 170-177.

[158] P.S. Rabinovitch, B.J. Reid, R.C. Haggit, T.H. Norwood and C.E. Rubin, Progression to cancer in Barrett's esophagus is associated with genomic instability, Lab. Invest. 60 (1988), 65-71.

[159] F. Ramaekers, A. Hopman and P. Voijs, Advances in the detection of ploidy differences in cancer by in situ hybridization, Anal. Cell. Pathol. 4 (1992), 337-344.

[160] P.H. Rao, S. Mathew, D.P. Kelsen and R.S.K. Chagani, Cytogenetic of gastric and esophageal adenocarcinomas. 3q deletion as a possible primary chromosomal change, Cancer Genet. Cytogenet. 81 (1995), 139-143.

[161] W.H. Raskind, T. Norwood, D.S. Levine, R.C. Haggitt, P.S. Rabinovitch and B.J. Reid, Persistent clonal areas and clonal expansion in Barret's esophagus, Cancer Res. 52 (1992), 2946-2950.

[162] A. Reichmann, P. Martin and B. Levin, Chromosomal banding patterns in human large bowel adenomas, Human Genetics 70 (1985), 28-31.

[163] B.J. Reid, P.L. Blount, C.E. Rubin, D.S. Levine, R.C. Haggitt and P.S. Rabinovitch, Flow cytometric and histological progression to malignancy in Barrett's esophagus: prospective endoscopic surveillance of a cohort, Gastroenterology 102 (1992), 1212-1219.

[164] B.J. Reid, R.C. Haggitt, C.E. Rubin and P.S. Rabinovitch, Correlation between flow cytometry and histology in detection of patients at risk for adenocarcinoma, Gastroenterology 93 (1987), 1-11.

[165] B.J. Reid, C.A. Sanchez, P.L. Blount and D.S. Levine, Barrett's esophagus: Cell cycle abnormalities in advancing stages of neoplastic progression, Gastroenterology 105 (1993), 119-129.

[166] D.K. Rex, O.W. Cummings, D.J. Helper, T.V. Nowak, J.M. McGill, G.Z. Chiao, P.Y. Kwo, K.T. Gottlieb, S.O. Ikeberry, F.G. Gress, G.A. Lehman and L.J. Born, 5-year incidence of adenomas after negative colonoscopy in asymptomatic average-risk persons, Gastroenterology 111 (1996), 1178-1181.

[167] M. Risio, S. Coverlizza, A. Ferrari, G.L. Candelaresi and F.P. Rossini, Immunohistochemical study of epithelial cell proliferation in hyperplastic polyps, adenomas and adenocarcinomas of the large bowel, Gastroenterology 94 (1988), 899-906.

[168] M. Risio, E. Geido, A. Di Vinci, A. Rapallo, N. Pujic, F.P. Rossini and W. Giaretti, DNA ploidy analysis within selected regions of colorectal adenomas containing carcinoma, Int. J. Onc. 3 (1993), 941-947.

[169] E. Rodriguez, P.H. Rao, M. Landanyi, N. Altorki, A.P. Albino, D.P. Kelsen, S.C. Jahnwar and R.S.K. Chaganti, $11 \mathrm{p} 13-15$ is a specific region of chromosomal rearrangement in gastric and esophageal adenocarcinomas, Cancer Res. 50 (1990), 6410-6416.

[170] H. Rubin, M. Chow and A. Yao, Cellular aging, destabilization, and cancer, Proc. Natl. Acad. Sci. USA 93 (1996), $1825-1830$.

[171] C.A. Rubio, Atypical mitosis in colorectal adenomas, Path. Res. Pract. 187 (1991), 508-513.

[172] J.C. Ruiz and G.M. Wahl, Chromosomal destabilization during gene amplification, Mol. Cell Biol. 10 (1990), 3056 3066.

[173] D. Salk, Werner's syndrome: a review of recent research with an analysis of connective tissue metabolism, growth control of cultured cells and chromosomal aberrations, Human Genetics 62 (1982), 1-15.

[174] D.A.K. Salk, H. Hoehn and G.M. Martin, Cytogenetics of Werner's syndrome cultured skin fibroblast: Variegated translocation mosaicism, Cytogenet. Cell Genet. 30 (1981), 92-107.

[175] A.A. Sandberg, Chromosome markers and progression in bladder cancer, Cancer Res. 37 (1977), 2590-2596.

[176] L.L. Sandell and V.A. Zakian, Loss of a yeast telomere: arrest, recovery, and chromosome loss, Cell 75 (1993), 729-739.

[177] M.S. Santisteban and G. Brugal, Fluorescence image analysis of the MCF-7 cycle related changes in chromatin texture. Differences between AT- and GC-rich chromatin, Anal. Cell. Pathol. 9 (1995), 13-28.

[178] T.M. Schroeder and J. German, Bloom's syndrome and Fanconi's anaemia: Demonstration of two distinctive patterns of chromosome disruption and rearrangement, Human Genetics 25 (1974), 299-306.

[179] H. Schipper, E.A. Turley and M. Baum, A new biological framework for cancer research, The Lancet 348 (1996), $1149-1151$.

[180] S. Sciallero, S. Bruno, A. Di Vinci, E. Geido, H. Aste and W. Giaretti, Flow cytometric DNA ploidy in colorectal adenomas and family history of colorectal cancer, Cancer 61 (1988), 114-120.

[181] S. Sciallero, W. Giaretti, L. Bonelli, E. Geido, A. Rapallo, M. Conio, P. Ravelli, L. Lombardo, G. Lapertosa and H. Aste, DNA content analysis of Barrett's esophagus by flow cytometry, Endoscopy 25 (1993), 648-651.

[182] J.V. Selby, G.D. Friedman, C.P. Quesenberry, Jr, and S.N. Weiss, A case-control study of screening sigmoidoscopy and mortality from colorectal cancer, New Engl. J. Med. 326 (1992), 659-662.

[183] S.E. Shackney, G. Berg, S.R. Simon, J. Coehn, S. Amina, W. Pommersheim, R. Yakulis, S. Wang, M. Uhl, C.A. Smith, A.A. Pollice and R.J. Hartsock, Origins and clinical implications of aneuploidy in early bladder cancer, Cytometry 22 (1995), 307-316. 
[184] S.E. Shackney, D.R. Burholt, A.A. Pollice, C.A. Smith, R.P. Pugh and R.J. Hartsock, Discrepancies between flow cytometric and cytogenetic studies in the detection of aneuploidy in human solid tumours, Cytometry 11 (1990), 94-104.

[185] S.E. Shackney et al., Model for the genetic evolution of human solid tumours, Cancer Res. 49 (1989), 3344-3354.

[186] D. Shibata, M.A. Peinado, Y. Ionov, S. Malkhosyan and M. Perucho, Genomic instability in repeated sequences is an early somatic event in colorectal tumourigenesis that persists after transformation, Nat. Genet. 6 (1994), $273-281$.

[187] D.A. Spandidos and N.M. Wilkie, Malignant transformation of early-passage rodent cells by a single mutated human oncogene, Nature 310 (1984), 469-475.

[188] S.J. Spechler, Barrett's esophagus, Seminars in Oncology 21 (1994), 431-437.

[189] M.E. Spooner and E.H. Cooper, Chromosome constitution of transitional cell carcinoma of the urinary bladder, Cancer 29 (1972), 1401-1412.

[190] E.J. Stanbridge, Human tumour suppressor genes, Ann. Rev. Genet. 24 (1990), 615-657.

[191] P.S. Steeg, G. Bevilacqua, L. Kopper, U.P. Thorgeirsson, J.E. Talmadge, L.A. Liotta and M.E. Sobel, Evidence for a novel gene associated with low tumour metastatic potential, J. Natl. Cancer Inst. 80 (1988), 200-204.

[192] R.G. Steinbeck, K.M. Helsemeyer and G.U. Auer, DNA ploidy in human colorectal adenomas, Anal. Quant. Cytol. Histol. 16 (1994), 196-202.

[193] H.F. Stich and H.D. Steele, DNA content of tumour cells. Quantitative genetic analysis of tumour progression, Cancer Met. Rev. 4 (1962), 173-178.

[194] H. Stopper, C. Körber, D. Schiffmann and W.J. Caspary, Cell-cycle dependent micronucleus formation and mitotic disturbances induced by 5-azacytidine in mammalian cells, Mut. Res. 300 (1993), 165-167.

[195] A.M.R. Taylor, J.M. Oxford and J.A. Metcalfe, Spontaneous cytogenetic abnormalities in lymphocytes from thirteen patients with ataxia telangiectasia, Int. J. Cancer 27 (1981), 311-319.

[196] J.R. Teyssier and D. Ferre, Frequent clonal chromosomal changes in human non-malignant tumours, Int. J. Cancer 44 (1989), 828-832.

[197] E. Thorud, O.P.F. Clausen and T. Abyholm, Fine needle aspiration biopsies from human testis evaluated by DNA flow cytometry, in: Flow Cytometry, O. Laerum, T. Lindmo and E. Thorud, eds, Vol. 4, Universitetsforlaget, Oslo, 1981.

[198] T.D. Tlsty, Cell-cycle control and genomic instability, Cancer Met. Rev. 14 (1995), 1-2.

[199] I.P.M. Tomlinson, M.R. Novelli and W.F. Bodmer, The mutation rate and cancer, Proc. Natl. Acad. Sci. USA 93 (1996), 14800-14803.

[200] B. Tribukait, DNA flow cytometry in carcinoma of the prostate for diagnosis, prognosis and study of tumour biology, Acta Oncologica 30 (1991), 187-192.

[201] A. Umar and A. Kunkel, DNA-replication fidelity, mismatch repair gene and genome instability in cancer cells, Eur. J. Biochem. 238 (1996), 297-307.

[202] H.F. van den Ingh, G. Griffioen and C.J. Cornelisse, Flow cytometric detection of aneuploidy in colorectal adenomas, Cancer Res. 45 (1985), 3392-3397.

[203] L.L. Vindelov and I.J. Christensen, A review of techniques and results obtained in one laboratory by an integrated system of methods designed for routine clinical flow cytometric DNA analysis, Cytometry 11 (1990), 753-770.

[204] L.L. Vindelov, I.J. Christensen, G. Jensen and N.I. Nissen, Limits of detection of nuclear DNA abnormalities by flow cytometric DNA analysis. Results obtained from a set of methods for sample-storage, staining and internal standardization, Cytometry 3 (1983), 332-339.

[205] B. Vogelstein et al., Genetic alterations during colorectal-tumour development, New Engl. J. Med. 319 (1988), $525-532$.

[206] B. Vogelstein et al., Allelotype of colorectal carcinomas, Science 244 (1989), 207-211.

[207] J.P.G. Volpe, Genetic instability of cancer: why a metastatic tumour is unstable and benign tumour is stable, Cancer Genet. Cytogenet. 34 (1988), 125-134.

[208] J.E. de Vries, F.H.A.C. Kornips, P. Marx, F.T. Bosman, J.P.M. Geraedts and J. Kate, Transfected c-Ha-ras oncogene enhances karyotypic instability and integrates predominantly in aberrant chromosomes, Cancer Genet. Cytogenet. $\mathbf{6 5}$ (1993), 35-43.

[209] R.A. Weinberg, Oncogenes, antioncogenes, and the molecular bases of multistep carcinogenesis, Cancer Res. 49 (1989), 3713-3721.

[210] H. Weiss, G.P. Wildner, K.H. Jacobasch, U. Heinz and W. Schaelicke, Characterization of human adenomatous polyps of the colorectal bowel by means of DNA distribution patterns, Oncology 42 (1985), 33-41.

[211] H. Wijkstrom, I. Granberg-Ohman and B. Tribukait, Chromosomal and DNA patterns in transitional cell bladder carcinoma. A comparative cytogenetic and flow-cytofluorimetric DNA study, Cancer 53 (1984), 1718-1723.

[212] A.C. Williams, S.J. Harper, C.J. Marshall, R.W. Gill, R.A. Mountford and C. Paraskeva, Specific cytogenetic abnormalities and K-ras mutation in two new human colorectal adenoma derived cell lines, Int. J. Cancer 52 (1992), $785-790$. 
[213] W.A. Williamson et al., Barrett's esophagus: prevalence and incidence of adenocarcinoma, Arch. Intern. Med. 151 (1991), 2212-2216.

[214] Z. Wirschubsky, P. Tsichlis, G. Klein and J. Sumegi, Rearrangement of c-myc, pim-1 and Mlvi-1 and trisomy of chromosome 15 in MCF- and Moloney-MuLV-induced murine T-cell leukemias, Int. J. Cancer 38 (1986), 739-745.

[215] N. Yamashita, T. Minamoto, A. Ochiai, M. Onda and H. Esumi, Frequent and characteristic K-ras activation and absence of p53 protein accumulation in aberrant crypt foci of the colon, Gastroenterology 108 (1995), 434-440.

[216] C. Yan Chen and D.V. Faller, Direction of p $21^{\text {ras }}$-generated signals towards cell growth or apoptosis is determined by protein kinase C and Bcl-2, Oncogene 11 (1995), 1487-1498.

[217] J. Yin, N. Harpaz, Y. Tong, Y. Huang, J. Laurin, B.D. Greenwald, M. Hontanosas, C. Newkirk and S.J. Meltzer, p53 point mutations in dysplastic and cancerous ulcerative colitis lesions, Gastroenterology 104 (1993), 1633-1639.

[218] J.J. Yunis and A.L. Soreng, Constitutive fragile sites and cancer, Science 226 (1984), 1199-1203.

[219] I. Zbieranowski, C. Demianiuk, V. Bell, W.A. Knape and D. Murray, Detection of false DNA aneuploidy and false DNA multiploidy in flow cytometric DNA analysis, Anal. Cell. Path. 5 (1993), 69-84.

[220] D. Zhang and B.R. Nicklas, "Anaphase" and cytokinesis in the absence of chromosome, Nature 382 (1996), 466-468.

[221] A. Zimmermann and F. Truss, The prognostic power of flow-through cytophotometric DNA determinations for testicular diseases, Anal. Quant. Cytol. 2 (1980), 247-251. 


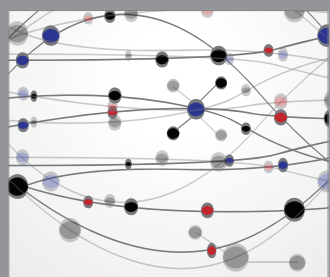

The Scientific World Journal
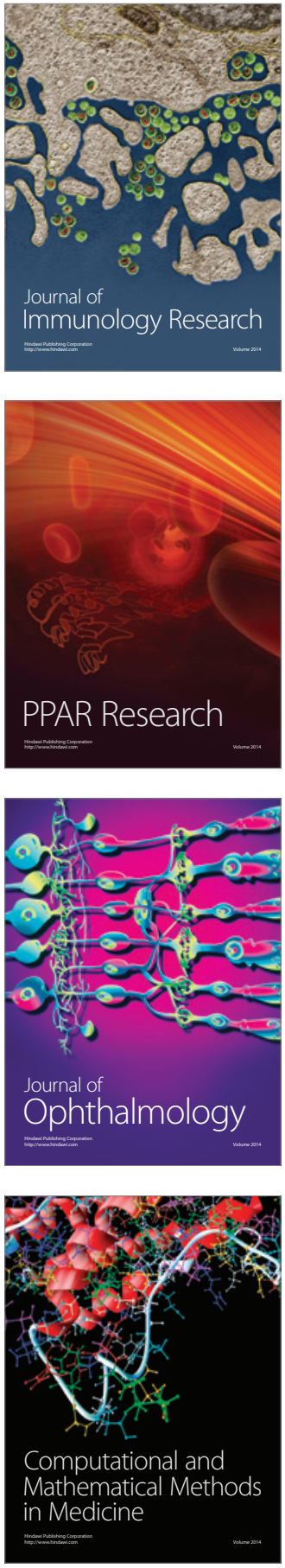

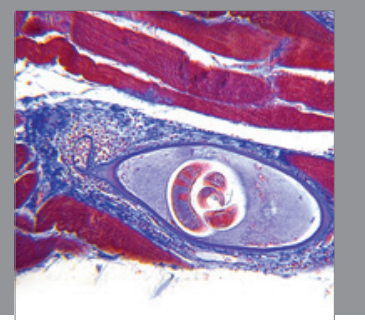

Gastroenterology

Research and Practice
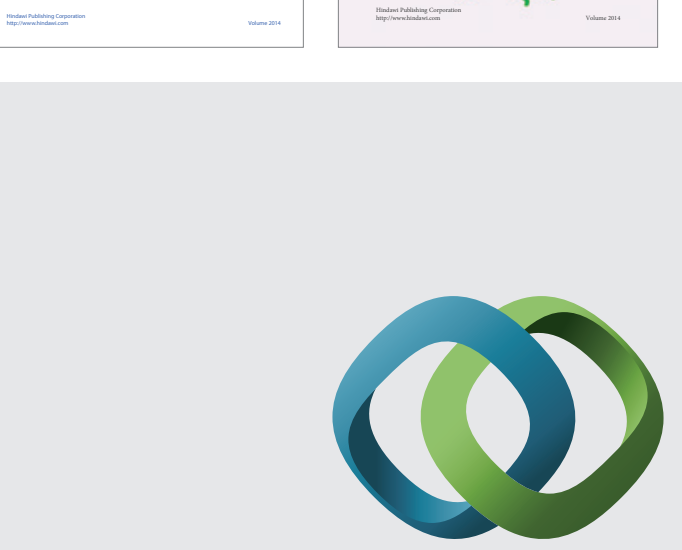

\section{Hindawi}

Submit your manuscripts at

http://www.hindawi.com
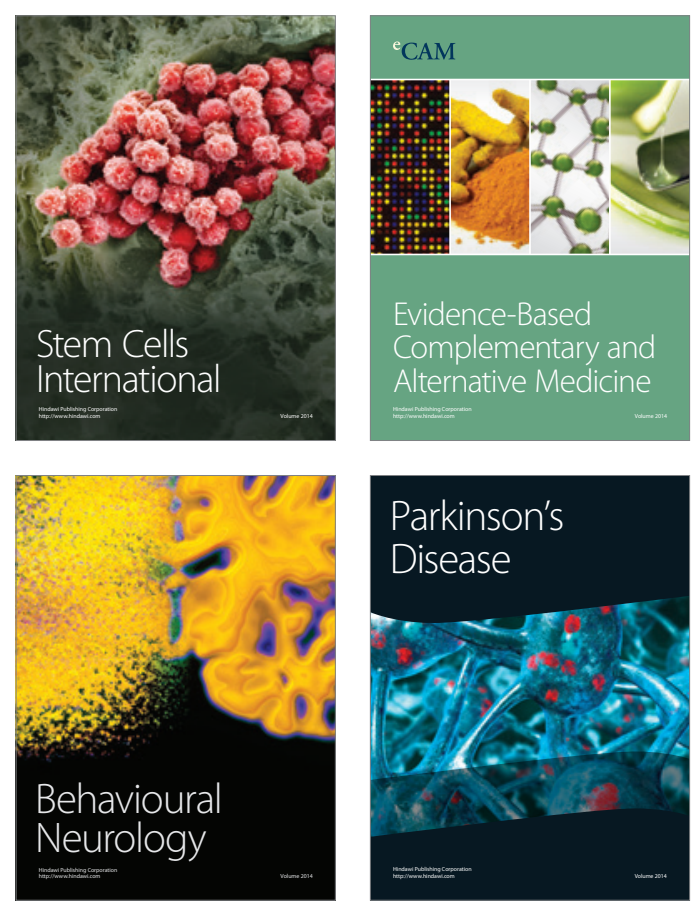

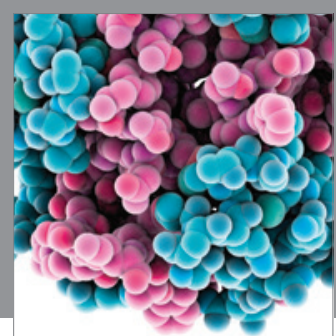

Journal of
Diabetes Research

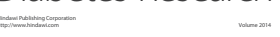

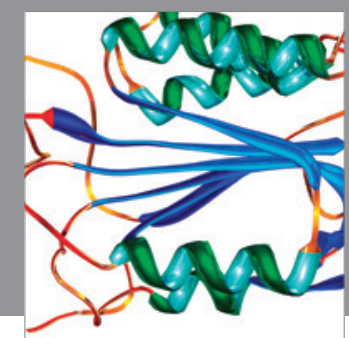

Disease Markers
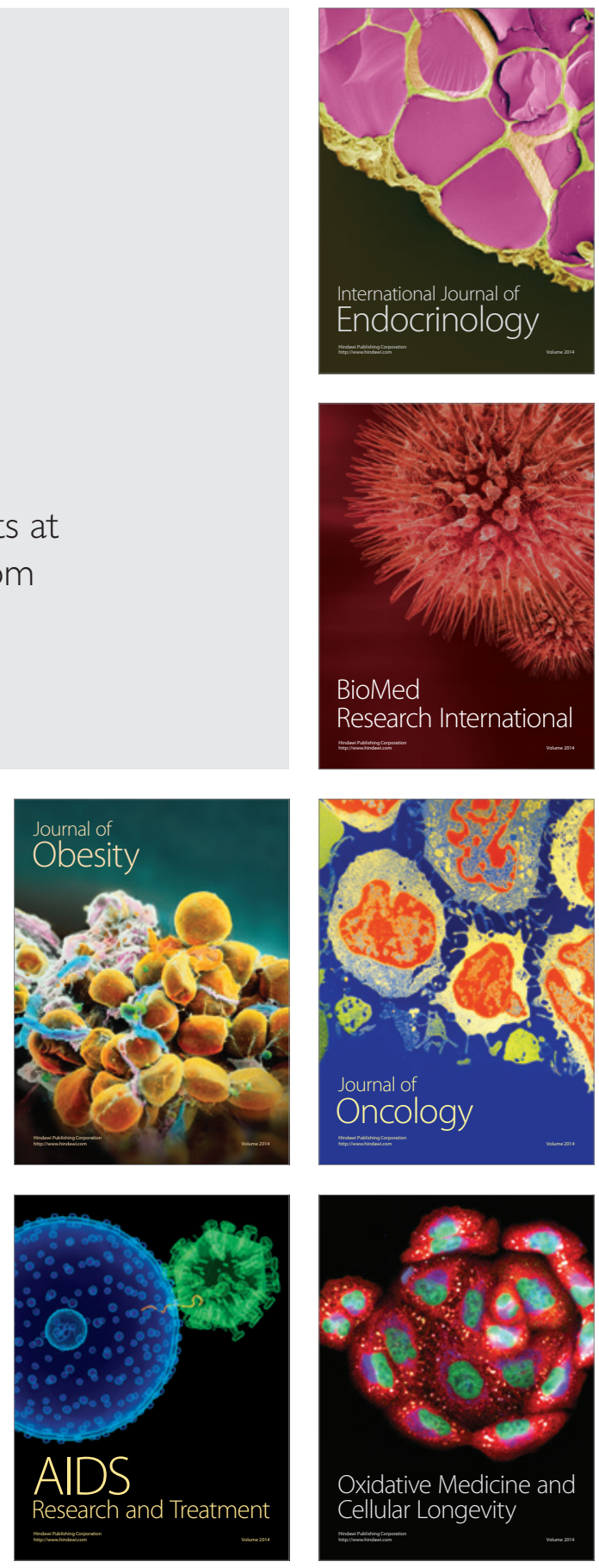